\title{
Strengthening the Multi-Party Presidential Government in Indonesia
}

\author{
Moh. Ilham A. Hamudy Ministry of Home Affairs, Indonesia \\ M. Saidi Rifki Ministry of Home Affairs, Indonesia
}

\begin{abstract}
The Multi-Party Presidential Government in Indonesia has reached a critical point. The 2.5 percent parliamentary threshold rule in the 2009 Election was incapable to address the issue. The parliamentary threshold was raised to 3.5 percent in 2014 , in the hope to reduce the number of party joining the election, but it failed to do so. There were 9 national parties participating in the 2009 election, and it will be increased to 16 in the 2019 election. Theoretically, the combination of multi-party parliament in a Presidential Government is rather strange. It is not surprising that the "conflict" between the president and parliament often occurs. There suppose to be a coalition supporting the government in parliament, but the coalition is not a firm one. The coalition did not have a significant influence in strengthening the presidential government. Therefore, this study intends to provide a complete picture of multi-party system practices while trying to provide solutions for strengthening the presidential government in Indonesia. To achieve this goal, this study uses the literature study method in collecting relevant information, using a qualitative approach. This approach is considered appropriate because multi-party phenomena and presidential systems are multidimensional. In contrast to previous research which was limited to the description and problems of multiparty systems, this research besides describing the system of government also provided moderate solutions that were considered to be in accordance with the Indonesian context. This study assumes that strengthening presidential systems can be done if the political parties are more modest. In addition, parliamentary support for the president must be optimized. The results of the study concluded that the strengthening of presidential systems must be carried out through the purification of the government system contained in the constitution, forming and strengthening the ranks of government coalitions in parliament, and carrying out a number of institutional engineering through various forms. These three things must be wrapped in a constitutional frame (amendments to the 1945 Constitution) and regulations (revisions to laws and government regulations). The amendments and revisions can be done through three corridors, namely the intra-parliamentary movement, the extra-parliamentary movement, and the referendum.
\end{abstract}

Keywords

Multi-Party Presidential Government; Government System; Election; A Parliamentary Threshold

INTRODUCTION

Referring to the constitution,

Moh. Ilham A Hamudy is a Researcher and concurrently the Head of Regional Economics at Research and Development Center of Research and Development Agency, Ministry of Home Affairs Republic of Indonesia. Email: ilhamhamudy80@gmail.com.

M. Saidi Rifki is a research assistant related to the Politics of Domestic Government in Research and Development Agency Ministry of Home Affairs, Republic of Indonesia since 2016. Email: saidirifky@gmail.com.
Indonesia adheres to a presidential government system. This can be seen from several provisions in the 1945 Constitution. In 2004 for the first time in Indonesia, the president and vice president election (Pilpres) were carried out directly by the people. The direct 
election was considered as a milestone in strengthening the presidential government. In reality, Indonesia does not firmly implement a presidential government system (Kompas.com, 2009), Instead, a kind of parliamentary sense was strongly felt. The root cause of that is the multi-party system. Since 1955, Indonesia held 11 general elections, each time, the election participants and the acquisition of seats in parliament are always filled by multiple parties. In every election, the number of the party always increases. Since the establishment of the country, hundreds of political parties have been formed and dozens of parties participating in Indonesia's election every time the fiveyear political contest is held (Suryakusuma, 1999).

This study emerges from the concern that the many political parties would be weakened and reduced the effectiveness of the presidential government. This is because the multiple-party in parliament would influence the government that is built as a parliamentary government and how much the president (executive) gets the support and becomes strong in the presidential system (Marijan, 2010). Various studies show that the combination of presidential government with multi-party parliament often leads to political problems. Linz and Velenzuela (1994) argued that the presidential government system applied to a multiparty political structure tends to give rise to conflicts between the presidential and parliamentary institutions and presents unstable democracy. This view is supported by Mainwaring and Shugart (1997) that the presidential-multi-party combination will give rise to a minority president and divided government, a condition where the president is very difficult to get political support in the parliament.

The results of studies in Latin America raise an important question for us: How is the presidential-multi-party practice in Indonesia? A presidential government would be difficult to implement on a multi-party structure. A coalition amongst the parties in parliament (but not common in presidential government) has become a fundamental need and is difficult to avoid in the presidential government - with a multi-party parliament structure. Especially since the coalition is very fragile and not firm because the parties in the coalition are not well disciplined and pragmatic. The personality and character of the president who likes to compromise 
and accommodating others causes the guarantees by coalition members to presidential government to be weakened support the government could be seen and run half-heartedly (Busroh, 2017). from the submission of four interpellation

Indobarometer's old research at the rights (Hak Interpelasl) and two times of end of 2007 showed that the majority of the public considered that Indonesia has too many political parties. At least 88.2 percent said so. In general, the people do not agree with a large number of political parties. The public wants five political parties (24 percent), three parties (21.6 percent) and 10 parties (18.3 percent). Thus, the requirements for the establishment of new political parties must be increased (to 68.2 percent) so that not everyone can establish political parties. (Okezone news, 2007).

Three years later, the Kompas poll also showed a relatively similar result. The majority of the public (94 percent) agree if the number of political parties in Indonesia is reduced. The governing with a combination of presidential government and a multi-party parliament model like today is considered less effective (Yuda, 2010).

The absence of guarantees from the coalition party for the effectiveness and stability of the government can be seen in several political events during the periods of 2004-2014 and 2014-2019 In the 2004-2009 administration, the lack of rights to inquire (Hak Angket) to the government which were approved by the majority of factions in the DPR (House of Representative), including factions which were the members of a pro-government coalition (Haris, 2014).

Again, in the 2009-2014 period, the coalition members' lack of solidarity in supporting the government was also shown, for example, several coalition member political parties agreed to the proposal to use the rights to inquire on the Century Bank bailout in 2009. The lack of guaranteed support from the coalition members was again seen in the period of 2014-2019, for example in the case of the appointment of the Chief of Police where coalition members showed resistance to the president's decision to withdraw the nomination of a Commissioner General as National Police Chief (dw.com, 2015).

These events clearly disrupt the effectiveness of government administration, because the executive body needs the support of the legislative body to ensure that the government would run smoothly Various government 
policy and program agendas may work if supported by an adequate budget, while the approval of the allocation and use of the budget is in the hands of the DPR ( $F$. Manan, 2017).

Several previous studies also showed that the multi-party presidential government system is not effective. A study by Ufen (2017), for example, concludes that the constant emergence of new political parties and the number of new parties in the parliament after the New Order caused the government to be vulnerable to deviations through the establishment of ad hoc institutions. The institution is used as a vehicle or protector for leaders or members of political parties. He argued that this is a new model of oligarchic politics, even though it was a presidential government strategy to strengthen the role of the president as head of state.

Other than Ufen, Mietzner (2016) also stated the same conclusion. Although the presidential government system in Indonesia is fairly stable, it can have a bad impact on the quality of democracy. The coercive approach taken by President Joko Widodo against several opposition parties, which later expressed support for him, was enough to make the government stable, However, Webb and White (2007) stated that this will create unclear political party stance. When the political parties easily switch between opposing or supporting government policy, the party will not have a consistent and discipline to be either one. For example, when an opposition party decides to join a government coalition party, it no longer acts as an opposition.

According to Tomsa (2017), the Indonesian presidential government system also became stagnant. He stated that the government system in Indonesia was complex, in which the president had to balance between his popularity as head of state and party leader or political actor who had the highest decision in his party. The political parties, that continue to grow in number, also fail to guarantee accountability and transparency. The election system in Indonesia has also made fragmentation of political parties at the local level that is higher at the national level and also increased 300\% from the three previous elections (1999, 2004 and 2009), particularly in Eastern Indonesia.

The constraints and limitations of the Indonesian multi-party presidential government system are the similar as Brazil's Junior, Pereira, and Biderman (2015) analyze coalitions between parties 
in Brazil, as well as the role played by institutions including the prerogative rights of party leaders in the DPR. Junior et al. saw that the party coalition in Brazil was very bad, and frequently did various political transactions ranging from budget, position, even rules to attract the opposition to support the government.

Another problem in presidential government systems is the failure of the system's checks and balances. As Suzanne (2016) found in her study in Nigeria. The dysfunctional system of checks and balances of government caused the unbalanced distribution of power. Although the executive, legislative and judicial relations are encouraged to be more stable to ensure good governance. As a result, the institutional security valve has become ineffective in the face of an increased culture of corruption and impunity. Misuse of authority and crisis of government is inevitable, compounded by the competition of the political elites to gain power, which further jeopardizes the stability of the government.

Based on those studies, practically only Chile is somewhat different. Chile is a country with a presidential government and multi-party systems whose governments are very stable, and not problematic One of the factors of its success is the commitment and consistency of the political parties in parliament in carrying out their party's ideology (Siavelis, 2014). However, it may not immediately possible to be referred to as the best practice to apply in Indonesia

In this context, this study attempts to address the above problems. Nevertheless, this study does not pretend to be able to solve various problems surrounding the application of a presidential government system in a multi-party environment, rather it seeks to find moderate solutions that are considered appropriate to the Indonesian context. This study assumes that strengthening the presidential government system may be achieved if the political parties are smaller in number. In addition, parliamentary support to the president must be optimized. Which means, the majority of parliament member (government political party coalitions) support the president's policy (Jones, 1995). To achieve this, there are several things that should be done, which are the purification of presidential government systems, forming and strengthening coalition, and institutional engineering 
through various forms. These three main things will be discussed in this study.

\section{METHOD}

This study uses the literature study method (Zed, 2004), by collecting information relevant to the presidential government system. The information was obtained from books, research reports, scientific articles, regulations and written sources, both printed or electronic copies. The study is using a qualitative approach. This approach is considered appropriate because multi-party phenomena and presidential systems are multidimensional. And both phenomena have interconnected variables and the exact nature of their connection is not known (Alwasilah, 2003). Meanwhile, facts and data collecting using literature studies by reviewing research systems from various countries from various literature such as previous studies in scientific journals, mainstream mass media (mainly related to the "conflict" between the president and parliament and the effectiveness of the running of government as a result of the application of a multi-party presidential government system).

\section{RESULT AND DISCUSSION}

In theory, Indonesia is a country with a presidential government system. This is based on the agreement of the founding fathers in the hearing of the BPUPK on 29 May-1 June 1945 and 10-17 July 1945. Soepomo has a big role in the formation of the Indonesian government, it was his idea that was approved by the participants of the session with a fairly complicated debate (Al-Arif, n.d).

Nevertheless, Indonesia experienced several changes to the government system throughout the years, since the enactment of the 1945 Constitution, the RIS Constitution, the Temporary Constitution, of 1950 and lastly, the amendment to the 1945 Constitution. Indonesia continues to seek an ideal form of government system. According to Manan (2006), it was only about two months of running of the presidential government, the government system was replaced by a parliamentary system under Prime Minister Sjahrir, The amendment began with the Announcement of the Vice President of the Republic of Indonesia Number $X$ (October 16, 1945) on the Change of Status of KNIP to an Agency that performs the duties of the DPR (House of Representatives) and partial part of the duties of the MPR (People's Consultative 
Assembly). It was followed with the impeached and fired by other institutions Government Announcement November 3, to whom the president is responsible to. 1945, regarding the political party. Lastly, the Government Announcement on November 14, 1945, on the establishment of a parliamentary cabinet with the assertion of cabinet responsibility to KNIP (as a temporary parliament). But in 1948, after the Amir Syarifuddin Cabinet fell, the parliamentary government system was changed again into a presidential government system led by Mohammad Hatta (as vice president). It was this government (Hatta Cabinet) which held the KMB with the Netherlands which ended the dispute between Indonesia and the Netherlands and the Netherland recognition of the Republic of Indonesia which name was changed to the United Republic of Indonesia.

Soemantri (1988) states, the system of government of the Republic of Indonesia based on the 1945 Constitution shows both aspects of the presidential and parliamentary government system or a mixed system of government. Similar with Soemantri, Kusnardi and Harmaily (1983) state that Indonesia under the 1945 Constitution adheres to a "quasipresidential" system of government because the president is accountable to the MPR so that the president can be

\section{Purification of Presidential Government Systems}

According to Isra (2010), the effort to purify of the presidential government system through the amendment to the 1945 Constitution was carried out four times (1999-2002). Purification is also carried out in the context of direct president/vice president elections (previously the election with a representative system mechanism) by amending Article 6 paragraph (2) of the 1945 Constitution which stipulated that "the President and Vice President are elected by the People's Consultative Assembly with the most votes" to Article 6A The 1945 Constitution which stipulated in paragraph (1) that, "The President and Vice President are elected as one pair directly by the people".

As part of the purification, it was also stated that the president is prohibited from dissolving the DPR. This prohibition is a consequence of the potential tension between the executive and the legislative body in the practice of presidential government systems. For example, during President Soekarno term of office, when the DPR-GR rejected the 1960 State 
Budget draft proposed by the government, President Soekarno took steps to dissolve the DPR-GR. Similarly, when President Abdurahman Wahid (Gus Dur) under threat to be dismissed by the MPR, Gus Dur released an announcement to freeze the DPR and MPR. Learning from those experience, as part of an effort to firming the presidential system, Article $7 \mathrm{C}$ of the 1945 Constitution states that the president cannot freeze and/or dissolve the DPR.

Another purification effort is on the existence of the MPR. Prior to the amendment to the 1945 Constitution, the MPR was placed as the holder of the people's sovereignty by affirming that the highest state power was in the hands of the MPR (die gezamte staatgewalt liege allein bei der Majelis).

Although purification has been carried out, the Indonesian presidential system is still inconsistent. The Indonesian presidential system is an interesting matter to be discussed since generally, any country uses a presidential government system only have two parties competing. Such as the United States, this is closely related to ensuring the strength of the government. If the elected president is from the Democratic Party, the Republican party will automatically become an opposition, and vice versa for the implementation of checks and balances process by the executive and legislative body.

Indonesia implements a presidential government system but does not have only two parties, it has a multi-party. What is interesting is if the elected president came from a party that is a minority in the parliament, even though it might be a big party, would the other parties holding more seat in the parliament than the elected president's party automatically become opposition? If so, we can imagine how weak the executive position is in running the government.

Even so, denying the existence of the multi-party is not realistic. The diverse nation and the political community in Indonesia cannot be accommodated in only two parties, such as in the United States. Therefore, at this point, the debate about the system of government is not about which system is better, but about which choice is more appropriate for a country based on social structure, political culture, and history because each system has advantages and disadvantages. After all, there is no perfect system. So, what is important is how the multi-party presidential system is modified in such a 
way that it can run well, and the focus is for the benefit of society in real terms. The most rational and realistic modification, for now, is to build coalitions between parties to support the president while slowly reducing the number of political parties in the election and in parliament.

It is necessary to move on to a mutual agreement that presidential coalition governments should be accepted as a political necessity and a democratic constitution. The coalition government proposition was then formulated in a number of terminologies, such as presidencialismo de coalizao (Abranches, 1988; Lanzaro, 2001). A number of experts suggested that the effectiveness of presidential government be seen from the side of its prototype, as it was in the design of the constitution. Does it adhere to the principle of separation of powers and separation of objectives as in the United States or adheres to the principle of unification of power and unification of objectives, as is commonly seen in Latin American countries or other presidentialist countries. The basic premise is stated as such, constitutional design determines how the ideal government system, and the government system will determine the electoral system (Lijphart, 1992).
Paragraph 20 Section (2) of the 1945 Constitution provides an explicit signal that the Indonesian presidential system of government is assumed to be effective if there is a unification of power and unification of objectives between the two branches of power, namely the executive and legislative branches. This can be seen from the provisions in the constitution article above "each draft law is discussed by the House of Representatives and the President for mutual agreement.

\section{Form and Strengthen the Coalition}

Empirical studies by experts show that coalitions in presidential systems are a common phenomenon. By analyzing all democratic countries between 19702004, Cheibub (2006), for example, proving that coalition governments in the parliamentary system occur as much as 39 percent, while in presidential systems 36.3 percent. Using the 1949-1999 data, Cheibub, Przeworski, dan Saiegh (2004) also found that in both systems, coalitions occurred more than 50 percent when the presidential party did not have a majority in the legislative body. As such, whether or not a coalition exists is not a differentiator factor between presidential and parliamentary government system. 
On the flip side of it, there are certain policies that might divide the support from the coalition party. This shift in support is common, even in a parliamentary government system (Asrinaldi, 2013). This does not mean that coalitions in presidential government systems are useless. Securing political support for presidential initiatives and policies is important. The existence of a coalition makes this more predictable and simpler than just relying on ad-hoc support from one policy to another. The lesson for Indonesian coalitions in presidential systems is political reality (Haris, 2008). Rather than condemning it, it is better to find a way to work to support the administration. The president and his coalition ranks must work harder to ensure that they have enough support in the DPR to pass various executive policies.

Moreover, it has been proven (in the 2013 Bank Century case, the Election Bill and the Mass Organization Bill 2017) that a party coalition that supports the President and has a seat in the cabinet does not automatically support the President's agenda in the DPR. The President must also work harder to ensure the solidity of his supporting parties, not enough to rely solely on support and guarantees from the party's general chairman. Perhaps the President can activate a more intensive approach to individuals or small groups of DPR members. The non-coalition party, the opposition, is not static. The number of opposition parties does not necessarily reflect the size of the opposition forces. With more personal approaches, there are those who can be approached to support the President's policies. All of this will make the President-DPR relationship process more dynamic and constructive (Hanan, 2010).

There are at least two types of coalitions that can be formed. First, a "relatively" permanent coalition. The coalition is a "relative" since the coalition in a presidential government system is usually weaker than coalition in the parliamentary government system. If the party supporting the coalition doesn't support the president policy, it will not result in the dissolution of the government in the presidential government system. While in the parliamentary coalition, if part of the coalition party withdrew their support, it is very possible that the government will be dissolved. It is said to be "permanent "because the coalition of supporters of the government tends to last for one period of the government (Law, 
2018). In the Indonesian context, the coalition should last up to five years.

Second is the ad hoc coalition. Political support for presidential policies can also be obtained per policy/issue. This support is piece-meal and temporary. The President can identify policy agendas that are compatible with certain parties, regardless of whether the party is from the coalition or opposition. Agenda A may be suitable for party $X$, agenda $B$ is compatible with party $\mathrm{Y}$, and agenda $\mathrm{C}$ can be supported by party Z. Support for various presidential policies will be very dynamic, depending on the skill of the president's political lobby team, in lobbying the parties that are expected to support it.

In presidential government systems, the president has an executive toolbox. There are many political powers/resources that the president can use to be exchanged for the ad hoc support. For example, some of the large parties elites are in financial difficulties and they have an obligation to immediately repay debts to the state or society (Tempo.co, 2012). The president may assist them in using state policies to pay for the obligation in the exchange with a political support for president policies (Hanan, 2011). The tool in the president's executive toolbox can also be used to "hit" his opponent. To avoid the "blow" of the president, the opposition party can exchange it with political support for the president's policy.

Even so, to anticipate issues that might hinder the government, a strong coalition is still a must. A strong coalition is a coalition built since the beginning of the presidential election. Coalitions based on ideological similarities, programs, and party lines are a necessity. The coalition cannot be done based on practicality, because it will be fragile.

The party system is measured by using the effective number formula of parties in parliament. Laakso and Taagepera (1979) shown, Effective Number of Parliamentary Parties (ENPP) of 7.47 or seven party systems. For example, even though the 2019 Election party system index in Indonesia was lower than the 2014 Election with an index, it was included in the extreme multi-party category or multi-party system without one dominant party. However, if the party system is calculated based on the portion of the coalition seats, the ENPP index produces 1.91 numbers or the bipartai party system.

On the side of the tendency to form the majority and the effectiveness of the government system. Data from the 
election results show that the distribution of seats in the five coalition political parties carrying the Incumbent pair controlled at least $60.70 \%$ of the total 575 seats in the DPR, while the elected president earned $55.33 \%$ of the votes. The configuration will have an impact on the situation that the president is elected, in addition to gaining a majority vote, he will also enjoy majority support in the DPR. Coherence in the form of unification of power and the unification of goals between branches of power occurs so that the potential for institutional conflict; the executive and legislature can be avoided. Thus, the effectiveness of the theoretical government system will be realized.

Theorizing the effectiveness of presidential government above certainly has a number of conditions. First, whether the coalition commitment formed from the beginning of the nomination of the presidential/vice presidential candidate pairs can be maintained or will be shaken, because the talks have begun with a number of parties from other camps. Second, commitment to coalition and running government programs in representative institutions also requires a measure of political compensation in the context of cabinet formation. Whether the support portion of each party member of the coalition in the DPR will be reflected through cabinet degrees. Third, is the discipline of the government coalition faction maintained during the administration. For example, the solidity of the coalition faction in passing laws or other policies that require the approval of two branches of power, both executive and legislative (Mellaz, 2019).

\section{Institutional Engineering}

Institutional engineering in this study is the engineering carried out in the electoral system, electoral district (electoral district), structuring of factions in parliament, and the timing of elections to strengthen the presidential government system.

As previously described, Indonesia with an extreme multi-party system has been proven to cause vulnerability and ineffectiveness of presidential government systems. The solution is a middle ground, the freedom to establish a party remains open, but it needs to be urgently pushed to be a simpler multi-party, even "a 2 party" parliament. Because, in the daily activities, the president is dealing with parties in parliament, not the parties running in the election. Therefore, what needs to be simplified is the number of parties in parliament, not only the number 
of election participants, to ensure that democracy and freedom to have a party are guaranteed (Yuda, 2010). This study offers four packages of parliamentary simplification strategies - rearranging the design of political institutions - through institutional engineering that can be pursued by the DPR and the government through the revision of the Election Law.

First, applying a district election system (plurality/majority system) or a mixed system (mixed member proportional). The First Past the Post (FPTP) system - one representative chosen from each electoral district - based on experience in several countries has proven effective in reducing the number of parties (Eggers \& Fouirnaies, 2013). The district system is more effective than the current system, especially with the plan to reduce the number of political parties. The reduction in the number of the political parties is useless if it is not followed by a reduction in the number of legislative seats. There are many advantages to the district system. The party can be more focused. Competition occurs between political parties, not between internal political parties. With a district system, it is hoped that the performance of DPR members would be better (Gaffar, 1999).
In the district system, every political party is only entitled to submit one legislative candidate. As such, if there are 16 political parties, then in one district there are only 16 legislative candidates. In addition, the district system also reduces the amount of work for the organizing committee, such as the General Election Commission (KPU) because the registration process for legislative candidates is easier. An alternative solution if the district system is still experiencing resistance is combining the district and proportional system into a mixed system (Nurhasim, 2014). Germany has a mixed election system that is interesting to learn from.

The Germany election system combines two different aspects, people often refer to it as a "balanced representation system" (dw.com, 2017a). In Germany, there are 598 seats in the German parliament, the Bundestag. Half of it 299 seats are won through the direct election system. Another half of it is won through a proportional election system based on the candidate list. Every voter chooses twice on one ballot. With the first voice, he chose the name of a candidate. This is the direct election part. Candidates with the most votes in one constituency will enter parliament. This system is 
called the majority election system. With a second vote, the voters choose the name of one party. The number of votes for one party will determine the number of seats won in parliament. This is the indirect election part. Which candidate to be the parliament member is determined by the party, by compiling a numbered list of candidates. This system is called the proportional election system The electoral system in Germany is a mixture of both direct and proportional systems (dw.com, 2017b).

Second, reduce the magnitude of the electoral area (district magnitude). The strategy to reduce the size of the electoral district in an evolutionary manner will also be a catalyst in reducing the number of political parties (Hix, Hortala-Vallve, \& Riambau-Armet, 2017). The smaller the size of the electoral district and the less the number of seats contested, the smaller the chance for the small party to get a seat. In the 2019 Election, the KPU determines 80 electoral districts (Dapi) which will be the stage for obtaining seats for the DPR, the provincial DPRD and the regency/city DPRD. That number increased from the 2014 Election which was only 77 electoral districts. The addition of the electoral district occurred in three regions. West Kalimantan, North
Kalimantan, and West Nusa Tenggara (cnnindonesia.com, 2018).

Referring to Law No. 7 of 2017 on Election, the addition of the number of electoral districts would mean the increase in the number of DPR seats. In the upcoming 2019 Election, there are 575 seats to be won. While in the 2014 Election the DPR seats were just 560. The number of electoral districts/municipal DPRD members throughout Indonesia will be 2,206 in the 2019 Election. That number increased compared to the 2014 Election which only 2,102 electoral districts throughout Indonesia. The increase in the number of electoral districts is linked with the increase in the number of seats in the DPRD (2,207 seats) of the 33 provinces throughout Indonesia. In the 2014 election, the total seats of DPRD were 2,112 . The number of seats in the regency/city DPRDs throughout Indonesia also increased, from 16,895 seats in 2014 to 17,610 seats in the 2019 Election (Mediaindonesia.com, 2018).

Reduction to the number of political parties to strengthen the presidential government is the main factor, which is the reason why the arrangement of seat allocations and electoral districts needs to be done Reducing the size of the DPR 
and DPRD electoral districts to 3-6 seats represent the DPR and DPR. (from 3-10 for the DPR and 3-12 for the (Rumahpemilu.org, 2016).

current DPRD) is the most effective way

So far, what has always been argued to strengthen the presidential system (BBC News Indonesia, 2017).

The size of the electoral district should be reduced to 3-6 seats or Small Multi-Member Constituency so that political parties are increasingly difficult to obtain seats. The size of the electoral area of 3-6 seats will force the party to compete/compete to offer programs for public benefit (Gaffar, 1999). The smaller the size of the electoral district, the harder it is to get a seat. The harder it is to get a seat, the higher the party's attention to members and sympathizers. What is happening now is that political parties can easily get seats, so that the attention and concern of political parties to their members and sympathizers tend to be limited to just before the election. (NDI, 2008).

However, reducing the size of the electoral district also means reducing the degree of representation. This problem can be overcome by setting political parties to represent the electoral districts if they get a seat in the electoral district. Political parties as participants in the DPR and DPRD election should indeed is the reduction of political parties in the parliament by raising the parliamentary threshold (Firdaus, 2010; Siahaan, 2016). In fact, the parliamentary threshold is not very effective in reducing the number of political parties in Indonesia. That threshold will only make competition between political parties to be increasingly fierce (Kompas.com, 2018). Because, in addition to the larger threshold, the number of political parties participating in the election is also increasing. The parliamentary threshold is proven not to reduce political parties in the DPR. The 2009 election with a threshold of 2.5 percent resulted in 9 political parties from 38 political parties.

The vote was so spread out, it was difficult to reach the 2.5 percent threshold. Then in the 2014 Election, the parliamentary threshold was 3.5 percent with the 12 political parties joining the election and 10 parties passed the threshold. In the 2019 election, the parliamentary threshold rose again to 4 percent (viva.co.id, 2018). However, at the same time, the number of political parties increased to 16 . Which means the votes that in the 2014 election vied by 12 
parties will be distributed to 16 political parties. At a certain level, the high parliamentary threshold will only cast out voters' votes. The community has come to the polling station (voting place) to vote, but because the political party does not pass, or the votes are wasted, it cannot be counted. The point is, that even if the parliamentary threshold is still raised, to reduce the number of political parties, the size of the electoral district must also be reduced.

Third, reduction of the number of factions (Breslaw, 2016) by increasing the minimum threshold requirements for the formation of fractions (fractional threshold). Ideally, in the DPR there should only about 3 or 4 , even 2 factions to ensure that the presidential government system would run more efficiently. If the faction in parliament is still more than two, the parliamentary faction needs to be engineered and "forced" constitutionally into two political blocs through the regulation of permanent coalitions. This model of two political forces is the appropriate strategy towards a "dual party" system in parliament, where there are only two large permanent coalition blocks in the DPR: supporters of the government and the opponent of the government. The main objective is to simplify the polarization of political forces in parliament to become "dual party" to create a more efficient and stable political process.

Therefore, the requirements for the formation of factions must be tightened to enable the faction to carry out its role more effectively. (Yuswanto, 2014). A minimum number of member for each faction need to be set. Ideally, the number of members in each faction is three times or more than the number of administration bodies (alat kelengkapan) of the DPR. That is, if the DPR currently has 17 Alat Kelengkapan in the form of commissions and bodies, then the minimum number of faction members is 51 persons or more, 100-150 persons, for example. This is based on the minimum requirements for fraction formation and refers to the number of commissions in the DPR that are 11 and six bodies which include the Legislation Body (Baleg), Budget Agency (Banggar), the State Financial Accountability Agency (Detik.com, 2018), Badan Urusan Rumah Tangga (BURT), Badan Musyawarah (Bamus), dan Badan Kehormatan (BK). With each fraction having a minimum number of members three times the number of DPR fittings, 
the representation function is guaranteed in a decision-making process.

With less number of factions, the commission function will run better, representation function would work, and the decision-making process will not be long-winded. (Sindonews.com, 2012). In fact, the 10 factions in the DPR are currently ineffective. There are several factions that are not able to empower their members to the fullest because the members are few. As a result, they are overwhelmed since there many duties that have to be performed simultaneously by the members. The ineffective performance by the faction impacted the DPR as a whole. The implementation of the duty of the representatives became neglected, the discussion of the bill was not completed, the quality dropped, and so on (rmol.co, 2018).

Fourth, simultaneous elections. The basic assumption of simultaneous presidential and legislative elections is to produce a government supported by a strong coalition in parliament. Because the coalition was built from the beginning, it led to a joint commitment to support the government from the start. Thus, the president can be effective in running the government. If the presidential and legislative elections take place simultaneously, there will be an effect of attraction (Lago, Lobo, \& Lago-Peñas, 2013). That the elected president will get the support of a political party with a dominant seat in the DPR (Kompas.com, 2016).

According to Jones (1995), there are at least two main aspects of the electoral system that must be taken into account if you want to simplify the party system or the availability of adequate political support for the strengthening of the presidential government system. First, the timing of the legislative and executive (presidential) elections. There are two variants here: separate implementation and simultaneous implementation. Second, the electoral formula for presidential elections. There are also two variants: plurality and majority run-off. In the plurality formula, presidential elections take place only one round. Whoever gets the most votes is the winner. In a majority run-off, a presidential candidate must win at least 50 percent more to become a winner. If there are no winners, the second round is followed by the first and second ranks from the first round. This majority run-off system is the system used for presidential elections in Indonesia to date. 
Meanwhile, the plurality mechanism implement a presidential government influences parties when it is implemented simultaneously with legislative elections. Parties tend to nominate one of the two most competitive candidates and lead to the gathering of legislative parties in the two candidates. When one of the candidates wins the presidential election, the support of the president in the legislature tends to be a majority or close to the majority Thus the combination of the presidential plurality election system implemented simultaneously with the legislative elections is the most likely to help strengthen the multi-party presidential system (Hanan, 2016).

\section{CONCLUSION}

The presidential government system in Indonesia has not shown optimal strengthening because it is faced with a multiparty system. The legitimacy of the elected president who should be the political capital for the president is often paralyzed when faced with the political process at the party elite level in the parliament. Efforts to build political coalitions cannot be avoided. However, the coalition that has been built so far tends to be pragmatic and more as a transactional politic than political development. Admittedly, it is not easy to system because it must be faced with an extreme multi-party system.

As described in the previous section, to strengthen the presidential government system, there are three things that need to be done, which are the purification of the government system in the constitution, forming and strengthening the ranks of government coalitions in parliament, and carrying out a number of institutional engineering. These three things must be done through constitutional amendments and revisions to the Law. The question is, in what corridor are these efforts carried out? This study offers three corridors that can be chosen as entry points to solve these problems.

\section{Intra-parliamentary movement}

This movement is a political action carried out systematically through a political process in formal political institutions. This means that the strengthening of the presidential government system is carried out through the formulation of regulations, both the constitution and the law, in the parliamentary meetings. For this reason, the amendment of the 1945 Constitution, or the revision of the Election Law which contains matters related to the president 
and vice president elections, the holding of elections, and the election of members of the DPR, DPD, and DPRD cannot be avoided.

The problem is, does the revision of the Law have to be done and implemented as early as possible? Certainly not! As stated above, such a technocratic idea cannot be carried out in the near future, because it is certainly detrimental to the political party concerned. The way out is that the regulation should be revised, but its implementation could be postponed to a few years afterward. There needs to be a time for preparation of the political superstructure and infrastructure, both within the political parties themselves and external political parties (government systems). It could be one to two periods of the presidential terms, or even more.

\section{Extra-parliamentary movement}

This movement is a political act carried out systematically, through ways outside the political process in formal political institutions. Actions manifested in movements such as mass action, strikes, various studies, discussions, seminars, both on and off campus that aim to make or demand change. The changes in question are strengthening the presidential government system. In that context, the role of civil society, the social movement as a counterweight to the parliamentary oligarchy becomes an important alternative. The effort to remind political parties that are getting more and more oligarchy must be carried out by the extra power of the parliament which includes the labor sector, students, farmers, the urban poor, NGO activists, women, journalists and the prodemocracy middle class, to fight for the strengthening of the presidential system contained in the constitution and law. The objective of this extra-parliamentary political work is to foster collective energy supporting the social movement and to prevent the presidential government system to move to the wrong direction.

\section{Referendum}

The referendum aims to create awareness of the people of their role as "constitution author". The people exist to create a "constitutional moment". The people as the owners of "constituent power" deserve to be heard and the referendum is the best way to know the will of the people. The implementation of the referendum is carried out when the country must decide on the most important issues. Strengthening this 
presidential government system is part of the country's important issues. So far, popular sovereignty has often been hijacked by party oligarchs. Therefore, the people must be involved so that they know and can ensure that the will to improve this nation is contained in the constitution or even the Law. In the context of strengthening the presidential government system, a referendum that seems to be appropriate is the obligator's referendum. That is, the people force the political elites to include the presidential government system strengthening agenda in a regulation, whether through constitutional amendments or revisions to laws and government regulations.

\section{REFERENCES}

Abranches, S. H. H. de. (1988). Presidencialismo de coalizão: 0 dilema institucional brasileiro. Dados, Revista de Ci ncias Sociais, 31(1), $5-34$.

Al-Arif, M. Y. (n.d.). Anomali Sistem Pemerintahan Presidensial Pasca Amandemen UUD 1945. Jurnal Hukum IUS QUIA IUSTUM, 22(2), 238-254.

Alwasilah, A. C. (2003). Pokoknya Kualitatif: Dasar-Dasar Merancang dan Melakukan Penelitian Kualitatif. Jakarta: Pustaka Jaya.

Asrinaldi. (2013). Koalisi Model Parlementer dan Dampaknya pada Penguatan Kelembagaan Sistem Presidensial di Indonesia. Jurnal Penelitian Politik, 10(2), 15.

BBC News Indonesia. (2017). Apa yang perlu Anda ketahui tentang UU Pemilu. Retrieved July 27, 2018, from

https://www.bbc.com/indonesia/indon esia-40678216

Breslaw, J. (2016). Fractional Representation Mandate: The mandate of the Special Committee on Electoral Reform includes, among others, three apparently contradictory principles. Montréal: Concordia University.

Busroh, F. F. (2017). Reformulasi Penerapan Electoral Threshold dalam Sistem Kepartaian di Indonesia. Jamal Lex Librum, 3(2), 513-524.

Cheibub, J. A. (2006). Presidentialism, Parliamentarism, and Democracy. Cambridge University Press. Cheibub, J. A., Saiegh, S. M., \& Przeworski, A. (2004). Government Coalitions and Legislative Success Under Presidentialism and 
Parliamentarism. British Journal of Eggers, A. C., \& Fouirnaies, A. B. (2013).

Political Science, 34(4), 565-587.

cnnindonesia.com. (2018). KPU

Tetapkan Jumlah Dapil dan Kursi

Pemilu 2019. Retrieved July 27, Firdaus, S. U. (2010). Relevansi 2018, from

https://www.cnnindonesia.com/nasio

nal/20180418181605-32-

291797/kpu-tetapkan-jumlah-dapil-

dan-kursi-pemilu-2019

detik.com. (2018). DPR Resmikan Alat

Kelengkapan Dewan Baru, Apa Itu?

Retrieved July 27, 2018, from https://news.detik.com/berita/d-

3927071/dpr-resmikan-alat-

kelengkapan-dewan-baru-apa-itu

dw.com. (2015). Presiden Jokowi Batal

Lantik Budi Gunawan Jadi Kapolri.

Retrieved September 18, 2018, from

https://www.dw.com/id/presiden-

jokowi-batal-lantik-budi-gunawan-

jadi-kapolri/a-18256377

dw.com. (2017a). Sekilas Tentang

Sistem Pemilu di Jerman. Retrieved July $\quad 27, \quad 2018, \quad$ from

https://www.dw.com/id/sekilas-

tentang-sistem-pemilu-di-jerman/a-

39181144

dw.com. (2017b). Sistem Pemilu

Campuran. Retrieved July 27, 2018,

from https://www.dw.com/id/sistem-

pemilu-campuran/a-4713509
Representation and district magnitude in plurality systems. Electoral Studies, 11(1), 267-277.

Parliamentary Threshold terhadap Pelaksanaan Pemilu yang

Demokratis. Jurnal Konstitusi, 8(2).

Gaffar, A. (1999). Politik Indonesia: Transisi Menuju Demokrasi. Jakarta: Pustaka Pelajar.

Hanan, D. (2010). Koalisi Sistem Presidensial - Kompas.com. Retrieved July 27, 2018, from https://nasional.kompas.com/read/20 10/05/11/03043266/koalisi.sistem.p residensial

Hanan, D. (2011). Sistem Presidensial Multi Partai, Suatu Anomali. Retrieved July 27, 2018, from http://www.perspektifbaru.com/wawa ncara/823

Hanan, D. (2016). Memperkuat Presidensialisme Multipartai di Indonesia: Pemilu Serentak, Sistem Pemilu dan Sistem Kepartaian. Jurnal Universitas Paramadina, 13, 14511475.

Haris, S. (2014). Praktik parlementer demokrasi presidensial Indonesia. Yogyakarta: Penerbit CV. Andi Offset. 
Hix, S., Hortala-Vallve, R., \& RiambauArmet, G. (2017). The Effects of District Magnitude on Voting Behavior. The Journal of Politics, 79(1), 356-361.

Isra, S. (2010). Pergeseran Fungsi Legislasi Menguatkan Model Legislasi Parlementer dalam Sistem Presidensial Indonesia. Jakarta: Raja Grafindo Persada.

Jones, M. P. (1995). Electoral Laws and the Survival of Presidential Democracies. Notre Dame: University of Notre Dame Press.

Junior, A. M., Pereira, C., \& Biderman, C. (2015). The Evolution of Theories about the Brazilian Multiparty Presidential System. Journal of Politics in Latin America, 71), 5-36. kompas.com. (2009). Sistem Presidensial Belum Berjalan Utuh. Retrieved September 14, 2018, from https://nasional.kompas.com/read/20 09/03/07/02461094/Sistem. Preside nsial.Belum.Berjalan.Utuh

kompas.com. (2016). UU Pemilu Baru Harus Memperkuat Sistem Presidensial. Retrieved July 27, 2018, from https://nasional.kompas.com/read/20 16/11/19/10523271/uu.pemilu. baru .harus.memperkuat.sistem. presidensi al

Kompas.com. (2018). Perludem: Ambang Batas Parlemen 4 Persen, Persaingan Parpol Semakin Sengit. Retrieved July 27, 2018, from https://nasional.kompas.com/read/20 18/05/12/12505291/perludemambang-batas-parlemen-4-persenpersaingan-parpol-semakin-sengit

Kusnardi, \& Ibrahim, H. (1983). Pengantar Hukum Tata Negara Indonesia (Cet. 5). Jakarta: Pusat Studi HTN.

Laakso, M., \& Taagepera, R. (1979). "Effective" Number of Parties. Comparative Political Studies, 12(1), 3-27.

Lago, I., Lobo, M. C., \& Lago-Peñas, S. (2013). Coattail Effects and the Political Consequences of Electoral Systems. Lisboa.

Lanzaro, J. (2001). Tipos de Presidencialismo y Modos de Gobierno en América Latina. Bibliotecas Virtuales de CLACSO. Buenos Aires.

Law, M. (2018). When Foes Become Friends and Friends Become Foes: Party Political Co-Operation and the Building and Sustaining of Coalitions The Political Party Co-Operation and 
The Building and Sustaining of Mellaz, A. (2019). Prospek Pemerintahan

Coalitions. Cape Town

Lijphart, A. (1992). Parliamentary Versus

Presidential Government. (A. Lijphart, Ed.) (cetak ulan). San Diego: Oxford University Press.

Linz, J. J., \& Valenzuela, A. (1994). The Failure of Presidential Democracy. Baltimore: Johns Hopkins University Press.

Mainwaring, S., \& Shugart, M. S. (1997).

Presidentialism and Democracy in Latin America. Cambridge: Cambridge University Press.

Manan, B. (2006). Lembaga Kepresidenan. Jakarta: FH UII Press. Manan, F. (2017). Relasi Eksekutif Legislatif Dalam Sistem Presidensial Multipartai di Indonesia. Jurnal Wacana Politik, 2(2).

Marijan, K. (2010). Sistem Politik Indonesia: Konsolidasi Demokrasi Pasca-Orde Baru. Jakarta: Kencana Prenada Media Group.

mediaindonesia.com. (2018). Alokasi

Dapil dan Kursi DPRD Kabupaten/Kota Naik. Retrieved July 28, 2018, from http://mediaindonesia.com/read/detail /155851-alokasi-dapil-dan-kursidprd-kabupatenkota-naik
Efektif. Retrieved June 17, 2019, from

https://mediaindonesia.com/read/detai 1/240812-prospek-pemerintahanefektifhttps://id.search.yahoo.com/yhs /web?hspart=shnl\&hsimp=yhs-

001\&type $=c 11078 \mathrm{dbc310492954f}$ e89f0131\&param1 =Firefox\&param2 $=1 \&$ param3 = campaignID\%3D586 \%26UserlD\%3D2139085697\&para $\mathrm{m} 4=$ XPbueSzfB

Mietzner, M. (2016). Coercing Loyalty: Coalitional Presidentialism and Party Politics in Jokowi's Indonesia. Contemporary Southeast Asia: A Journal of International and Strategic Affairs, 38(2), 209-232.

NDI. (2008). Hubungan dengan Konstituen. Washington, DC. Retrieved from https://www.ndi.org/sites/default/files/ Hubungan_Dengan_Konstituen_BAH. pdf

Nurhasim, M. (2014). Fisibilitas Sistem Pemilu Campuran: Upaya Memperkuat Sistem Presidensial di Indonesia. Jurnal Penelitian Politik, $11(1), 369$.

okezonenews.com. (2007). Jumlah Parpol di Indonesia Kebanyakan. Retrieved July 7, 2018, from 
https://news.okezone.com/read/2007/

12/18/1/69126/jumlah-parpol-di-

indonesia-kebanyakan

rmol.co. (2018). Formappi: Kinerja DPR

Rendah. Retrieved July 27, 2018, from

http://politik.rmol.co/read/2018/05/2

2/340984/Formappi:-Kinerja-DPR-

Rendah-

rumahpemilu.org. (2016). Penataan

Ulang Dapil. Retrieved July 27, 2018, from

http://rumahpemilu.org/penataan-

ulang-dapil/

Siahaan, N. H. (2016). Formula

Penyederhanaan Jumlah Partai

Politik di Parlemen pada Pemilihan

Umum Indonesia. Politika: Jurnal IImu Politik, 71), 102-114.

Siavelis, P. M. (2014). The Fault Lines of Coalitional Presidentialism: Cabinets, Quotas, Iron Circles and the Second Floorin Chile. In 23rd World Congress of the International Political Science Association (pp. 1-33). Montreal, Canada.

sindonews.com. (2012). Pengetatan pembentukan fraksi di DPR. Retrieved July 27, 2018, from https://nasional.sindonews.com/read/ 669394/12/pengetatan- pembentukan-fraksi-di-dpr-

1346634892

Soemantri, S. (1988). Ketetapan MPR (S)

sebagai Salah Satu Sumber Hukum

Tata Negara. Bandung: Remaja Karya.

Suryakusuma, J. I. (1999). API: Almanak Parpol Indonesia. Bogor: SMK Grafika Mardi Yuana [printer].

Suzanne, F., \& Omololu, F. (2016). Power Relations Among Institutions in Nigeria's Presidential System: Issues and Contentions. International Journal of Politics and Good Governance, 77), 1-22.

Syamsuddin Haris. (2008). Mendesain Koalisi Presidensial. Retrieved July 27, 2018, from http://lipi.go.id/berita/mendesainkoalisi-presidensial/2080

tempo.co. (2012). Triliunan Rupiah Uang Negara untuk Lumpur Lapindo. Retrieved July 28, 2018, from https://nasional.tempo.co/read/40678 9/triliunan-rupiah-uang-negara-untuklumpur-lapindo

Tomsa, D. (2017). Regime resilience and presidential politics in Indonesia. Contemporary Politics, 1Q1), 1-20.

Ufen, A. (2017). Party presidentialization in post-Suharto Indonesia. Contemporary Politics, 24(3), 1-19. 
viva.co.id. (2018). Ambang Batas

Parlemen 4 Persen Bikin Pileg 2019

Makin Seru. Retrieved July 28, 2018, from

https://www.viva.co.id/berita/politik/1

035475-ambang-batas-parlemen-4-

persen-bikin-pileg-2019-makin-seru

Webb, P., \& White, S. (2007). Party

Politics in New Democracies. Oxford, USA: OUP Oxford.

Yuda, H. (2010). Kerentanan

Presidensial-Multipartai. Retrieved

July $\quad 7, \quad 2018, \quad$ from

https://nasional.kompas.com/read/20

10/07/28/03092245/kerentanan.pre

sidensial-multipartai

Yuswanto. (2014). Kedudukan Fraksi di

Dewan Perwakilan Rakyat

Berdasarkan UU No 17 Tahun 2014

tentang MPR, DPR, DPD, dan DPRD.

JOM Fakultas Hukum, 3(2), 1-12.

Zed, M. (2004). Metode Penelitian

Kepustakaan. Jakarta: Yayasan

Pustaka Obor Indonesia. 